This accepted author manuscript of article: Eper-Pápai, I., Mentes, Gy. Comparison of two extensometric stations in Hungary

is copyrighted and published by Elsevier. It is posted here by agreement between Elsevier and MTA.

The definitive version of the text was subsequently published in: Geodynamics, 2014, Volume 80, pp. 3-11, October 2014, ISSN: 0264-3707.

DOI: <http://dx.doi.org/10.1016/i.jog.2014.02.007>

Available under license CC-BY-NC-ND. 


\section{Comparison of two extensometric stations in Hungary}

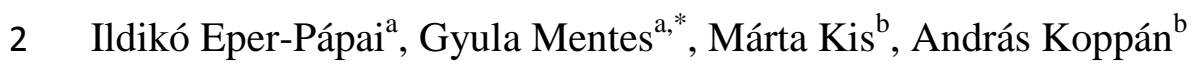

$3 \quad{ }^{\mathrm{a}}$ Geodetic and Geophysical Institute, Research Centre for Astronomy and Earth Sciences,

4 Hungarian Academy of Sciences, Csatkai E. u. 6-8, 9400 Sopron, Hungary. E-mail:

5 papai@ggki.hu, Phone: +36 99 508368, E-mail: mentes@ggki.hu, Phone: +36 99508348

$6{ }^{\mathrm{b}}$ Geological and Geophysical Institute of Hungary, Stefánia u.14, 1143 Budapest, Hungary.

7 E-mail: $\underline{\text { kis.marta@mfgi.hu, koppan.andras@ mfgi.hu }}$, Phone: +3613843302

$8 \quad$ Corresponding author E-mail address (Gy. Mentes): mentes@ggki.hu

9 Phone: +36 99508348

\section{Abstract}

Quartz-tube extensometers are used to measure rock deformations in two geodynamic observatories in Hungary in order to contribute to the investigation of recent tectonic movements on the area of the Pannonian Basin. One of the observatories is situated on the border of the Alps at Sopronbánfalva and is set in the metamorphic (gneiss) material of the mountains. The other station is in the basically karstic environment of the Mátyáshegy (Mátyás Hill) near Budapest. The aim of this paper is to investigate how the local conditions, such as structure of the observatory, topography or geologic features of the surrounding rocks, lead to additional or modified deformations of the extensometric stations. Data collected over eight years were processed and analysed to compare the observatories taking into account geologic, lithologic and topograpic properties of the measurement sites. Tidal and coherence analysis of the continuous strain measurements revealed that the instrument at Sopronbánfalva is more sensitive to atmospheric pressure loading than the extensometer at Mátyáshegy. Signal to noise values from the data processing of the short period variations support the higher stability of tidal strain measurements at Mátyáshegy. The strain rates measured by 
extensometers in both observatories are in good agreement with the strain rates inferred from GPS measurements of the Hungarian GPS Geodynamic Reference Network and the Central European GPS Reference Network.

Keywords: Earth tides; Extensometer; Barometric pressure; Geodynamic observatory; Strain rate

\section{Introduction}

Extensometric measurements provide horizontal deformation data which incorporates the short period tidal variations as well as local tectonic deformations in the long run, but the recorded data are influenced by different effects depending on the local conditions of the measurement site. Many publications deal with the influence of the construction and the surroundings of the instrument's site appearing as cavity, topographic and lithologic effects (e.g., Harrison, 1976; Brimich et al., 1998; Gebauer et al., 2009). Other works have been published on the effect of atmospheric pressure loading on horizontal deformation measurements (e.g., Müller and Zürn, 1983; Dal Moro and Zadro, 1998; Kroner et al., 2005; Steffen et al., 2006; Zürn et al., 2007) under the conditions at a given measurement site and a given type of measurement device.

In Hungary two observatories were established for seismic and gravity measurements and for observation of tectonic movements and tides of the solid Earth: the Mátyáshegy Gravity and Geodynamic Observatory (MGGO) in Budapest in a cave in Mátyáshegy and the Sopronbánfalva Geodynamical Observatory (SGO) in Sopronbánfalva in an artificial gallery (Fig. 1). In the MGGO two extensometers were installed in 1981 and 1985 (Latinina et al., 1984) and in the SGO one extensometer in 1990. All instruments are quartz-tube extensometers with capacitive transducers. Their construction and calibration are described in detail by Mentes (2010). Since the measuring instruments are of the same type and capability to monitor deformations, it is a good opportunity to compare two geodynamic observatories 
which lie in different geologic, topographic and tectonic environments. Features of the geodynamic deformation measurements at both sites in the high and low frequency ranges of the signals are presented in this paper.

\section{Observation sites}

\subsection{Sopronbánfalva Geodynamic Observatory}

The Sopronbánfalva Geodynamic Observatory is located on the Hungarian-Austrian border in the Sopron Mountains. The area belongs to the extensions of the Eastern Alps (Alpokalja region), which extend eastward to the Rába fault (Fig. 1) regarded as the easternmost termination of the Alps in Hungary. The crystalline rocks of the Alpokalja region crop out in an area of $40 \mathrm{~km}^{2}$ and are composed of folded, medium grade crystalline shists and subordinate low-grade tectonites (muscovite gneiss and leucophyllite). The crystalline basement of the mountains is covered by Neogene sediments. The Sopron Mountains consist of metamorphic rocks of Palaeozoic age such as gneiss and different mica schists (Haas, 2001). The geological map of the surroundings of the observatory can be seen in Fig. 2. The observatory is an artificial gallery driven into an outcrop of the muscovite gneiss which belongs to the most schistose variety of the medium-grained gneisses called 'Sopron type gneisses' (Kisházi and Ivancsics, 1985). The rock cover above of the observatory is about 60 $\mathrm{m}$. There are no fractures and faults in the vicinity of the observatory. The yearly mean value of the temperature is $10.4{ }^{\circ} \mathrm{C}$ in the gallery and the yearly and daily temperature variations are less than $0.5{ }^{\circ} \mathrm{C}$ and $0.05{ }^{\circ} \mathrm{C}$, respectively. The relative humidity is $90 \%$ and it is nearly constant. The gallery where the extensometer is placed is thermally insulated but not perfectly hermetically sealed. It means that there is a slow air circulation via the duct for the electric cables of the instruments. This ventilation does not change the temperature in the gallery and the instrument is not directly sensitive to air pressure variations (Mentes, 2000). The coordinates of the SGO and the length and azimuth of the extensometer are given in Table 1. 
The ground plane of the observatory and the location of the extensometer, which is nearly perpendicular to the rock wall are shown in Fig. 3.

\subsection{Mátyáshegy Gravity and Geodynamic Observatory}

The Mátyáshegy Gravity and Geodynamic Observatory is situated in the karstic environment of Mátyáshegy in the north-western suburban part of Budapest. The Mátyáshegy is a part of the Buda Mountains, in north central Hungary, belonging to the regional unit 'Transdanubian Mountains' (Fig. 1). The karstic cave system of the hill is the longest $(13.465 \mathrm{~km})$ exposed cave system of West Hungary. The galleries were created by thermal water from the upper Triassic flinty limestone and the discordantly bedding marine upper Eocene nummulitic limestone. These formations are parts of the karstic water reservoir of the hydrology of this area. The highest parts of the cavity reach up into the concordant bryozoan Marl. The tunnels and galleries of the observatory were based on the natural cave system and were artificially formed, mainly in the upper Eocene nummulitic limestone formation. Fig. 4 shows the topographic map of the surroundings of the observatory and its entrance in the area of the quarry located on the south-western side of the hill. The ground plane of the observatory with the long (E1) and short (E2) extensometers is shown in Fig. 5. The galleries run under about $30 \mathrm{~m}$ of rock cover; the temperature variation in the inner galleries is less than $0.2^{\circ} \mathrm{C}$ over a year. The level of the karstic water is about a hundred meters deeper than the level of the station. The River Danube flows about $2 \mathrm{~km}$ away from the observatory.

\section{Method}

Extensometric data recorded between 2005 and 2012 were used for calculations and for comparison of the measurement sites. In both cases the sampling rate is one minute. High frequency noises (well above the tidal range) are removed by built-in electric filters. Step and spike disturbances were corrected and gaps in the data series were filled with adjusted theoretical values in the course of preprocessing. The volume of the gaps is below $3 \%$ per a 
year at SGO and about $10 \%$ for E2 at MGGO. However, the rate of the missing data was also $3 \%$ for E2 in 2012. Continuous operation of E1 extensometer was interrupted for periods of many months due to technical problems in 2011 and 2012. The signals were finally sampled to one data/hour rate.

Features and transfer characteristics of the deformation measurements in the short-term band of variations were examined by means of tidal analysis. Calculations were completed by the ETERNA 3.40 Earth tide data processing package (Wenzel, 1996), using the Wahr-Dehant Earth model (Wahr, 1981; Dehant, 1987) and the HW95 tidal potential catalogue (Hartmann and Wenzel, 1995). A built-in high-pass filter of the program package (with a cut-off frequency of $0.8 \mathrm{cpd}$ ) was used during the tidal evaluation. The residual strain data of the tidal analysis were subjected to a Fourier transformation. The signal transfer properties of the two stations were compared by tidal and coherence analyses. The admittances between strain and the outer temperature were determined by a simple linear regression method. Coherence analysis between theoretical and measured tide was used to investigate the transfer function of the observatories (Formenti, 1999).

\section{Results}

\subsection{Tidal analysis}

A data series collected over eight years of the extensometer (SE) in the SGO (Fig. 3) and of the extensometers E1 and E2 in the MGGO (Fig. 5) were subjected to tidal analysis decomposing the data into one year segments. Evaluation of the data measured by extensometer E1 - which resulted in highly distorted tidal parameters - was left out of the investigation. Since the systematic checking and yearly calibration of the E1 extensometer show proper functioning of the instrument in all other respects, the disturbed transfer characteristics of the tidal signals is probably due to the relative position of the extensometer to the gallery system of the observatory (see Fig. 5). The value of the tidal parameters from 
analysis varies between $2-5 \%$ at both measurement sites in the consecutive years, so data processing of 2012 represents the multi-year measurement period. Adjusted tidal amplitudes and the amplitude factors (measured/theoretical amplitudes) along with the standard deviations of the adjustment for each component are listed in Table 2. The most striking difference is the reduced diurnal amplitudes in the SGO. The main measured amplitudes are $44-60 \%$ of the theoretical tidal deformation values. At the same time the $\mathrm{S} 2$ component in the semidiurnal band is higher by a factor of 1.5 than it should be. Reduced amplitudes of E2 are also adjusted in the diurnal band, which is similar to the SE results, but the differences between the measured and theoretical values are much smaller. The most conspicuous difference appears here in the K1 diurnal amplitude which decreased $25 \%$.

Since atmospheric pressure variations are among the main loading factors which affect the deformation measurements at almost all kind of measurement sites (e. g. Rabbel and Zschau, 1985; Sun et al., 1995; Onoue and Takemoto , 1998; Kroner et al., 2005), pressure data series measured in the observatories were taken into account and included in the tidal analysis. Data processing results are presented in Table 2. In Fig. 6 the adjusted tidal amplitudes from the analysis procedures can easily be compared. At Sopronbánfalva the linear regression correction of the strain data by air pressure yielded an increase of about $5-10 \%$ in the diurnal band, while there is a more prominent decrease of $40 \%$ at the S2 component, due to which the $\mathrm{S} 2$ amplitude significantly improved compared to the theoretical value. From the Mátyáshegy E2 data the analysis of the pressure-effect corrected extensometric series resulted in insignificant, maximum $2 \%$, amplitude variations. This difference in the pressure correction results are reflected also by the pressure sensitivity of the observatories, i.e. $4.5 \mathrm{nstr}$ $\mathrm{hPa}^{-1}$ in the SGO is against the value of the coefficient of $0.5 \mathrm{nstr} / \mathrm{hPa}$ in the MGGO. If the deformation records are corrected for barometric pressure applying the above correction factors in the time domain, the standard deviation of the residual signals (which are the 
theoretical tides subtracted from the measured data) decrease from 6.1 to $5.1 \mathrm{nstr}$ at the SGO and from 2.6 to $2.5 \mathrm{nstr}$ at the MGGO due to the correction.

The noticeable difference in the effect of atmospheric pressure variations at the two measurement sites is demonstrated in Fig. 7. Here the residual of the high-pass filtered strain data, which is provided by ETERNA among the analysis results, were subjected to a Fourier transformation. Fast Fourier Transformation amplitudes of the residuals - after uncorrected strain and pressure corrected strain analyses - are compared for both observatories in the tidal frequency band (0-2.5 cpd). In the Sopronbánfalva data, an apparent decrease of the residual amplitudes can be seen, especially in the 1 cpd band, while in Mátyáshegy amplitude changes can hardly be noticed. The effect of the barometric pressure correction is characterised also by numerical values: the average standard deviations of the tidal amplitudes (Table 2) and the average spectral noise of the residual amplitudes (Fig. 7) decreased in the $1 \mathrm{cpd}$ band (0.8-1.2 cpd) by $41 \%$ at Sopronbánfalva and $4 \%$ at Mátyáshegy, while in the 2 cpd band (1.8-2.2 cpd) by $22 \%$ at Sopronbánfalva and below $1 \%$ at Mátyáshegy. The values from the different calculation methods agree with each other within $1 \%$ in $1 \mathrm{cpd}$ and $2 \%$ in $2 \mathrm{cpd}$ bands.

Overall characteristic of the tidal parameter determination at the investigated observatories is concluded from Table 2. The determination is twice as accurate at the MGGO than it is at the SGO for the comparison of the standard deviations of amplitude values for the main waves, and of the standard deviations of weight unit of the adjustments. It matches the outcome of the pressure correction of the data.

\subsection{Coherence analysis}

The two observatories were tested also by coherence analysis to determine how they transfer the tidal signal. The coherence was calculated between theoretical and measured strain tide as input and output signals of the Earth-observatory-system. The transfer function of the system can be seen in Fig. 8. At the SGO the coherence is better than 0.95 in the semidiurnal band, 
while in the diurnal band it is about 0.8 . At the MGGO the coherence values are better than in the SGO which means that the transfer of the tidal signal is less damped than at the SGO.

\subsection{Long term variations}

Deformation measurement data collected over eight years from the two observatories were investigated. The recorded strain data of the Sopronbánfalva extensometer are drawn in Fig. 9 and curves of the E1 and E2 extensometers in the Mátyáshegy Observatory can be seen in Figs. 10 and 11. The long-term variations are approximated in the Figures by linear trend lines fitted to each data series along the recording period 2005-2012. The steepness of the trend lines is the average strain rate in the investigated period. The measured strain rates are summarised in Table 3 which also contains the strain rates measured in the MGGO by Varga and Varga (1994) between 1990 and 1992. The peak to peak magnitudes of the yearly rock strain variations caused mainly by the outer temperature variations (Mentes, 2000) determined after removing the trend from the curves - and the admittances between strain and the outer temperature are listed in Table 3. This yearly period at SE and E1 clearly appears in Figs. 9 and 10, while it is inconspicuous in the record of E2 (Fig. 11). The jumps and steep changes in the strain records of the MGGO (Figs. 10 and 11) can be in connection with the karstic water level changes under the observatory (Varga and Varga, 1994).

\section{Discussion}

Tidal analysis results reveal that the Mátyáshegy E2 instrument has a better capability to transfer data of the horizontal high frequency deformations than the extensometer in the SGO. Different behaviour of the extensometers due to atmospheric pressure loading can be disclosed if the pressure parameter is included in the tidal analysis and the strain data is corrected by a simple linear regression. Almost one order of magnitude higher regression value resulted for SGO $\left(4.5 \mathrm{nstr} \mathrm{hPa}^{-1}\right)$ than for MGGO $\left(0.5 \mathrm{nstr} \mathrm{hPa}{ }^{-1}\right)$. At the $\mathrm{SGO}$ a 
significant improvement of the tidal adjustment resulted, while in Mátyáshegy the effect is not detectable.

Beyond the similar instrument construction and the similar length of the galleries where the instruments are placed, the overlaying topography of the measurement sites is also similar. At the same time the rock coverage over the extensometers is two times higher at Soprobánfalva than at Mátyáshegy, the gallery system of the MGGO is much more complex - due to the original dissolved cave forms - than that of the SGO and a major difference exists in the azimuths of the instruments. From point of the modifying cavity effect - being one of the main site factors to be taken into consideration - a finite element model calculation resulted in an $8 \%$ increase of tidal rock deformation at the MGGO site. Such model calculations are not at our disposal for the SGO, though from the literature the order of the disturbing cavity effect for tidal strain, depending on the measurement arrangement and geometry, is about $1-10 \%$ (Harrison,1976; Sato and Harrison 1990). Thus, since the highest distortion of tidal amplitudes in the SGO varies between 40-60\%, this correction item cannot be resolved here. Lithologic parameters of the surrounding rocks at the measurement sites which describe the different rock materials are listed in Table 4. On the basis of the model calculations of Gebauer et al. (2009, 2010), where the cavity, topographic and lithologic effect on horizontal deformations under atmospheric pressure load were investigated, the results of their conclusions can be applied to these observatories in the increasing order of the magnitude of the effect:

- The extent of the cavity effect for the lithologies of these observatories is about $0.1 \mathrm{nstr}$ $\mathrm{hPa}^{-1}$, it is too small to be comparable with the difference in atmospheric pressure load effect between SGO and MGGO. At the same time the galleries of SE and E2 are of almost the same size and length. 
- Since the rock cover above the instruments is different, a $20-30 \%$ increase in the effect of topography can be supposed at Sopronbánfalva (60 m) compared to Mátyáshegy (30 m), but similarly to the previous effect its magnitude is small (below $0.5 \mathrm{nstr} \mathrm{hPa}^{-1}$ ) and it may explain only a minor part of the difference.

- From model calculations, a difference in the deformation effects in the order of about $2-2.5$ $\mathrm{nstr} \mathrm{hPa}^{-1}$ derives from the observatories having different rock material parameters and this value much better approaches the difference of the pressure effects which were provided by tidal analysis.

The above mentioned pressure load effects are related to a uniform pressure load condition. Dynamic loading cases are also incorporated in the finite element modelling of Gebauer et al. (2009, 2010). Since at Sopronbánfalva the gallery of the extensometer is parallel and at Mátyáshegy the gallery of E2 is almost perpendicular to the prevailing wind direction, which is the same above the regions of the observatories, the significantly higher pressure effect is in good agreement with the modelling results.

On the basis of eight years of measurements it seems that two extensometers (SE and E1) with almost the same azimuth, though far away from each other geographically, behave similarly in the sense of yearly deformation changes. Nevertheless the different yearly amplitudes should be noticed. The similarity between the conditions of the instruments is the position of the galleries (where they are placed) relative to the topography of the surface forms, the steep scarps, of the observatories. However, the Mátyáshegy Observatory has a cave system while at Sopronbánfalva the galleries were made only for the instruments. This complex gallery system of the MGGO leads to the different transfer mechanism induced by temperature variations in the case of E1 and E2 (Figs. 10 and 11). Due to their free unhindered deformation, the rock walls between the galleries in the MGGO absorb a part of the deformation energy caused by barometric pressure and temperature variations. This can 
explain the lower pressure admittance and temperature induced peak to peak yearly strain variations in the MGGO compared to SGO (Table 3).

The highest rate of the long-term deformation changes at Sopronbánfalva can be attributed to the geographical location of the instrument. The area belongs to the marginal mountainous region of the Pannonian Basin with mostly crystalline bedrock types, and this East Alpine region is characterised by different vertical deformation velocities compared to the central parts of the Pannonian Basin (Cloetingh et al., 2005; Caporali, 2009; Dombrádi et al., 2010). The folding and compression of the weak lithosphere absorbs the strain in the Pannonian Basin (Dombrádi et al., 2010) which explains the small strain rates measured in the Mátyáshegy Observatory. Extensometer E2 is nearly parallel to the maximum horizontal stress direction assumed by Bada et al. (2007a, b) and it measures a higher rate than E1 (Table 3) which lies almost perpendicular to the direction of E2. These local strain rates are in good accordance with the strain rates measured by geodetic methods (see Table 3 ). The strain rates determined from GPS measurements in the Hungarian GPS Geodynamic Reference Network and the Central European GPS Reference Network (Grenerczy et al., 2000, 2005) are three orders of magnitude smaller than the values measured by the extensometers. It can be explained by the difference of the measurement techniques. While the extensometer measures local strain rates, only global strain rates for large areas can be determined from GPS measurements. The faults between GPS stations and earthquakes in the region release the strain (Bada et al., 2007b; Bus et al., 2009). In the region of the SGO the strain rate measured by GPS is twice the value obtained in Central Hungary. Varga et al. (2002) determined a strain rate of $-0.08 \mu$ str year $^{-1}$ from the Hungarian Triangulation Network in the Budapest region, which is the same value measured by the E1 extensometer in the MMGO. Although extensometric measurements are influenced by local tectonic processes (e.g., orogenic forces), they describe the recent tectonic movements in the Pannonian Basin very well. 


\section{Conclusions}

The uniform construction of the extensometers in the Mátyáshegy Gravity and Geodynamic Observatory and in the Sopronbánfalva Geodynamic Observatory ensures that in the course of comparison any differences in the measurement characteristics can be attributed to geologic, topographic properties and meteorological conditions of the measurement sites.

Tidal analysis of the extensometric data between 2005 and 2012 revealed that the measured tidal amplitudes are close to the theoretical values in the MGGO while they are 44-60\% smaller in the diurnal band in the SGO. The difference in the tidal signals (also proved by coherence analysis) can be attributed to the different barometric pressure sensitivity of the

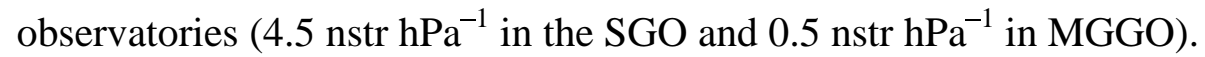

The results of the barometric pressure correction show that while in the MGGO a simple regression correction yields good improvement of the signal-to-noise ratio in the strain data, in the SGO a more sophisticated reduction method is needed which takes into account regional and possibly global air pressure data to correct for the effect of passing weather fronts.

The long-term thermal effect in the MGGO is about the half of the one in the SGO. The difference between the pressure and thermal sensitivity of the observatories is due to the different geologic, lithology parameters, gallery system and the position of the instrument relative to the topography of the measurement sites.

In contrast with the different transfer characteristics of the observatories in the tidal domain and the high long-term disturbances in the MGGO, probably caused by karstic water variations, the measured strain rates are in good agreement with the GPS measurements in the Hungarian GPS Geodynamic Reference Network and the Central European GPS Reference Network. 
The investigated geodynamic observatories and extensometers are parts of an extensometric observatory network on the territory of the Pannonian Basin. Therefore the analysis results may be utilized when the deformation measurements of the network are processed and the specific sensitivity of the measurement locations can lead to satisfactory corrections both in the high and low frequency ranges of the signals. It may contribute to a unified evaluation and interpretation.

\section{Acknowledgements}

The authors are grateful to three anonymous reviewers for their valuable comments and suggestions which helped to improve the paper. This work was funded by the Hungarian National Research Fund (OTKA) under project No. K 109060. Special thanks to Tibor Molnár for his careful maintenance of the instruments.

\section{References}

Bada, G., Grenerczy, Gy., Tóth, L., Horváth, F., Stein, S., Cloetingh, S., Windhoffer, G., Fodor, L., Pinter, N., Fejes, I., 2007a. Motion of Adria and ongoing inversion of the Pannonian Basin: Seismicity, GPS velocities and stress transfer. In: Stein, S., Mazzotti, S., (Eds.), Continental Intraplate Earthquakes: Science, Hazard, and Policy Issues. Geological Society of America Special Papers 425 (16), 243-262, http://dx.doi.org /10.1130/2007.2425. Bada, G., Horváth, F., Dövényi, P., Szafián, P., Windhoffer, G., Clothing, S., 2007b. Present day stress field and tectonic inversion in the Pannonian basin. Global Planet. Change 58, 165180.

Brimich, L., Kohút, I., Kostecký, P., 1998. Influence of the Cavity Effect on Tidal Measurements. In: Ducarme, B., Paquet, P. (Eds.), Proceedings of the 13th International Symposium on Earth Tides, pp. 397-412.

Budai, T., Gyalog, L. (Eds.), 2009. Geological Map of Hungary for Tourists. Geological Instite of Hungary, Budapest. 
Bus, Z., Grenerczy, Gy., Tóth, L., Mónus, P., 2009. Active crustal deformation in two seismogenic zones of the Pannonian region - GPS versus seismological observations. Tectonophysics 474, 343-352.

Caporali, A., 2009. Lithospheric flexure, uplift and expected horizontal strain rate in the Pannonian Carpathian region. Tectonophysics 474, 337-342.

Cloetingh, S., Mațenco, L., Bada, G., Dinu, C., Mocanu, B., 2005. The evolution of the Carpathians-Pannonian system: interaction between neotectonics, deep structure, polyphase orogeny and sedimentary basins in a source to sink natural laboratory. Tectonophysics 410, 1-14.

Dal Moro, G., Zadro, M., 1998. Subsurface deformations induced by rainfall and atmospheric pressure: tilt/strain measurements in the NE Italy seismic area. Earth Planet. Sci. Lett. 164, 193-203.

Dehant, V., 1987. Tidal parameters for an unelastic Earth. Phys. Earth Planet. Inter. 49, 97116.

Dombrádi, E., Sokoutis, D., Bada, G., Cloetingh, S., Horváth, F., 2010. Modelling recent deformation of the Pannonian lithosphere: Lithospheric folding and tectonic topography. Tectonophysics 484, 103-118.

Formenti, D., 1999. What is the coherence function and how can it be used to find measurement and test setup problems. Sound and Vibration, Questions and Answers, Sage Technologies, Morgan and Hill, California, 2-3.

Gebauer, A., Kroner, C., Jahr, T., 2009. The influence of topographic and lithologic features on horizontal deformations. Geophys. J. Int. 177, 586-602, http://dx.doi.org/10.1111/j.1365246X.2009.04072.x. 
Gebauer, A., Steffen, H., Kroner, C., Jahr, T., 2010. Finite element modelling of atmosphere

347 loading effects on strain, tilt and displacement at multi-sensor stations. Geophys. J. Int. 181, 348 1593-1612, http://dx.doi.org /10.1111/j.1365-246X.2010.04549.x.

349 Grenerczy, Gy., Kenyeres, A., Fejes, I., 2000. Present crustal movement and strain 350 distribution in Central Europe inferred from GPS measurements. J. Geophys. Res. $351 \quad 105$ (B9), 21835-21846.

352 Grenerczy, Gy., Sella, G., Stein, S., Kenyeres, A., 2005. Tectonic implications of the 353 GPS velocity field in the northern Adriatic region. Geophys. Res. Lett. 32, L16311, 354 http://dx.doi.org /10.1029/2005GL022947.

355 Haas, J. (Ed.), 2001. Geology of Hungary. Eötvös University Press, Budapest, pp. 315.

356 Harrison, J.C., 1976. Cavity and topographic effects in tilt and strain measurements. J.

357 Geophys. Res. 81, 319-328.

358 Hartmann, T., Wenzel, H.G., 1995. The HW95 tidal potential catalogue. Geophys. Res. Lett. $35922(24), 3553-3556$.

360 Kisházi, P., Ivancsics, J., 1985. Genetic petrology of the Sopron crystalline schist sequence. 361 Acta Geol. Hu. 28 (3-4), 191-213.

362 Kroner, C., Jahr, T., Kuhlmann, S., Fischer, K.D., 2005. Pressure induced noise on horizontal 363 seismometer and strainmeter records evaluated by finite element modelling. Geophys. J. Int. 161, 167-178, http://dx.doi.org /10.1111/j.1365-246X.2005.02576.x.

Latinina, L.A., Szabó, G., Varga, P., 1984. Observations of the deformation of the Earth's crust in the Mátyáshegy cave near Budapest. Acta Geod. Geophys. Mont. Hung. 19, 197-205.

367 Mentes G., 2000. Influence of Temperature and Barometric Pressure Variations on 368 Extensometric Deformation Measurements at the Sopron Station. Acta Geod. Geophys. Hung. 369 35 (3), 277-282. 
Mentes, Gy., 2010. Quartz tube extensometer for observation of Earth tides and local tectonic deformations at the Sopronbánfalva Geodynamic Observatory, Hungary. Rev. Sci. Instrum. 81, 074501, http://dx.doi.org /10.1063/1.3470100.

Müller, T., Zürn, W., 1983. Observation of gravity changes during the passage of cold fronts. J. Geophys. 53, 155-162.

Onoue, K., Takemoto, S., 1998. Atmospheric pressure effect on ground strain observation at Donzurubo Observatory, Nara, Japan. In: Ducarme, B., Paquet, P. (Eds.), Proceedings of the 13th International Symposium on Earth Tides, pp. 157-164.

Rabbel, W., Zschau, J., 1985. Static deformations and gravity changes at the Earth's surface due to atmospheric loading. J. Geophys. 56, 81-99.

Sato, T., Harrison, J.C., 1990. Local effects on tidal strain measurements at Esashi, Japan. Geophys. J. Int. 102, 513-526.

Steffen, H., Kuhlmann, S., Jahr, T., Kroner, C., 2006. Numerical Modeling of the Barometric Pressure-Induced Noise in Horizontal Components for the Observatories Moxa and Schiltach. J. Geodyn. 41, 242-252.

Sun, H.P., Ducarme, B., Dehant, V., 1995. Effect of the atmospheric pressure on surface displacement. J. Geodesy 70, 131-139.

Varga, P., Varga, T., 1994. Recent horizontal deformation in the Pannonian Basin measured with extensometers. Acta Geod. Geophys. Hung. 29, 57-80.

Varga, P., Verbitzkie, T.Z., Latinina, L.A., Brimich, L., Mentes, G., Szádeczky-Kardos, G., Eperne, P.I., Guseva, T.V., Ignatishin, V.V., 2002. Horizontal deformation of the Earth's crust in the Carpathian region. (In Russian), Science and Technology in Russia. 58 (7) - 59 (1), 58.

Wahr, J.M., 1981. Body tides on an elliptical, rotating, elastic and oceanless Earth. Geophys. J. R. Astr. Soc. 64, 677-703. 
395 Wenzel, H.G., 1996. The nanogal software: Earth tide data processing package ETERNA 396 3.30. Bull. d'Inf. Marées Terr. 124, 9425-9439.

397 Zürn, W., Exß, J., Steffen, H., Kroner, C., Jahr, T.,Westerhaus, M., 2007. On reduction of 398 long-period horizontal seismic noise using local barometric pressure. Geophys. J. Int. 171, $399 \quad 780-796$. 


\section{Figure captions}

402 Fig. 1. Extensometric stations in Hungary.

403 Fig. 2. Geological map (Haas, 2001) of the surroundings of the SGO.

404

405

406

407

408

409

410

411

412

413

414

415

416

417

418

419

420

421

422

Fig. 3. Ground plane of the SGO with the instruments.

Fig. 4. Topographic map of the surroundings of the Mátyáshegy Observatory (Budai and Gyalog, 2009).

Fig. 5. Ground plane of the MGGO with the instruments.

Fig. 6. Amplitudes of tidal components from ETERNA analysis of extensometric data from Sopronbánfalva (SE) and Mátyáshegy (E2) observatories. U, C and T denote amplitudes from analysing raw data, data corrected for barometric pressure by ETERNA and theoretical tide, respectively.

Fig. 7. Fast Fourier Transformation amplitudes of tidal analysis residuals at the SGO and MGGO. a) and c) residual amplitudes after strain analysis, b) and d) residual amplitudes after local barometric pressure corrected strain analysis.

Fig. 8. Transfer characteristic (coherence function between the theoretical and measured tides) of the Earth - observatory - instrument system at the SGO and at the MGGO.

Fig. 9. Extensometric raw data at the SGO from 1 Jan. 2005 to 31 Dec. 2012.

Fig. 10. Extensometric raw data measured by extensometer E1 at the MGGO from 1 Jan. 2005 to 31 Dec. 2012.

Fig. 11. Extensometric raw data measured by extensometer E2 at the MGGO from 1 Jan. 2005 to 31 Dec. 2012. 


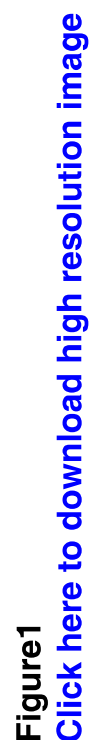

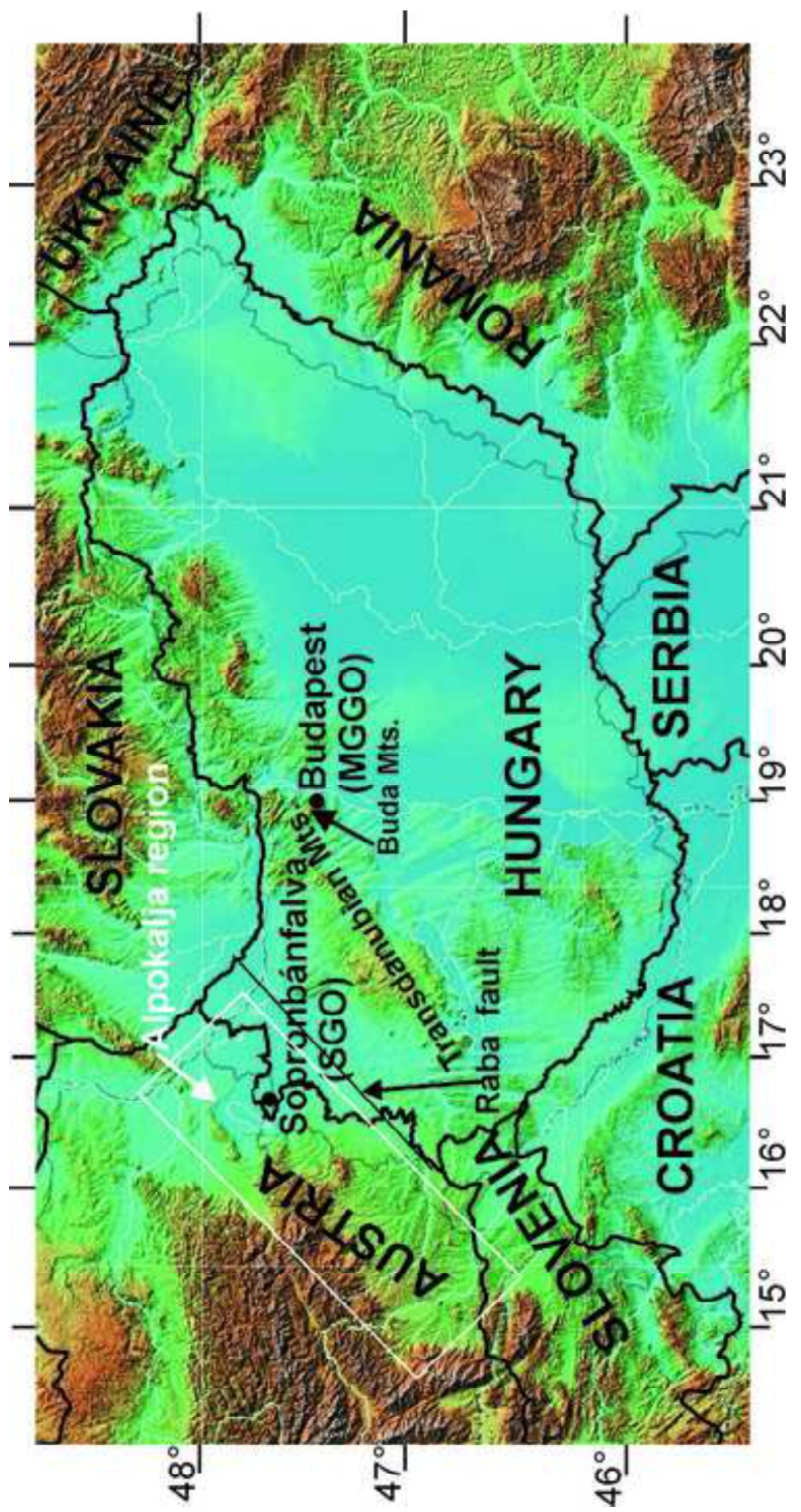




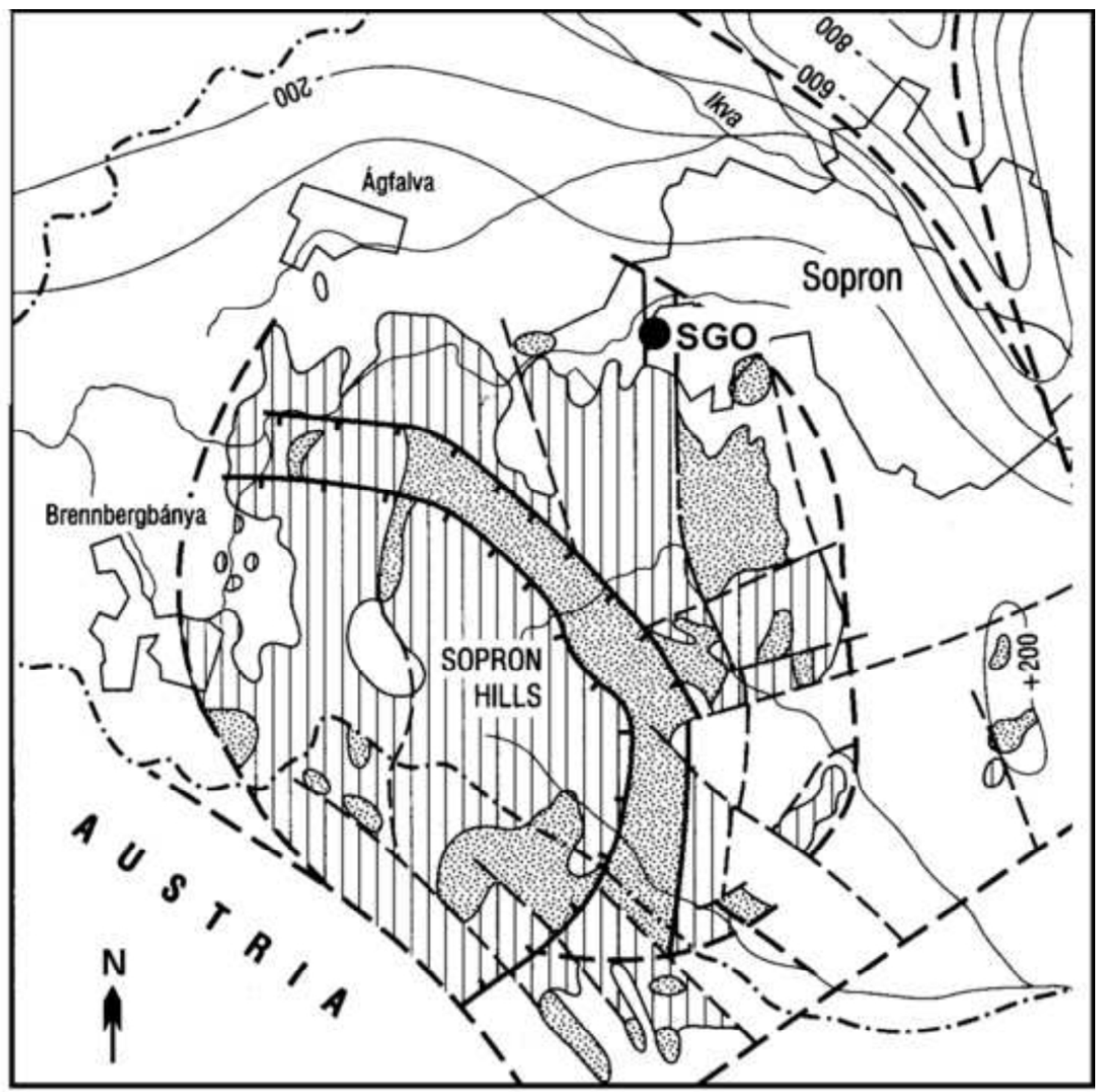

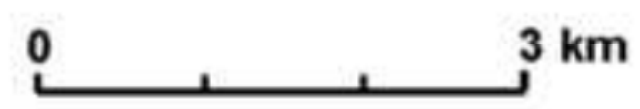

Sopron Gneiss Formations

Sopron Micaschist Formation
I- faults

I. scale boundary

Iـ- nappe boundary 


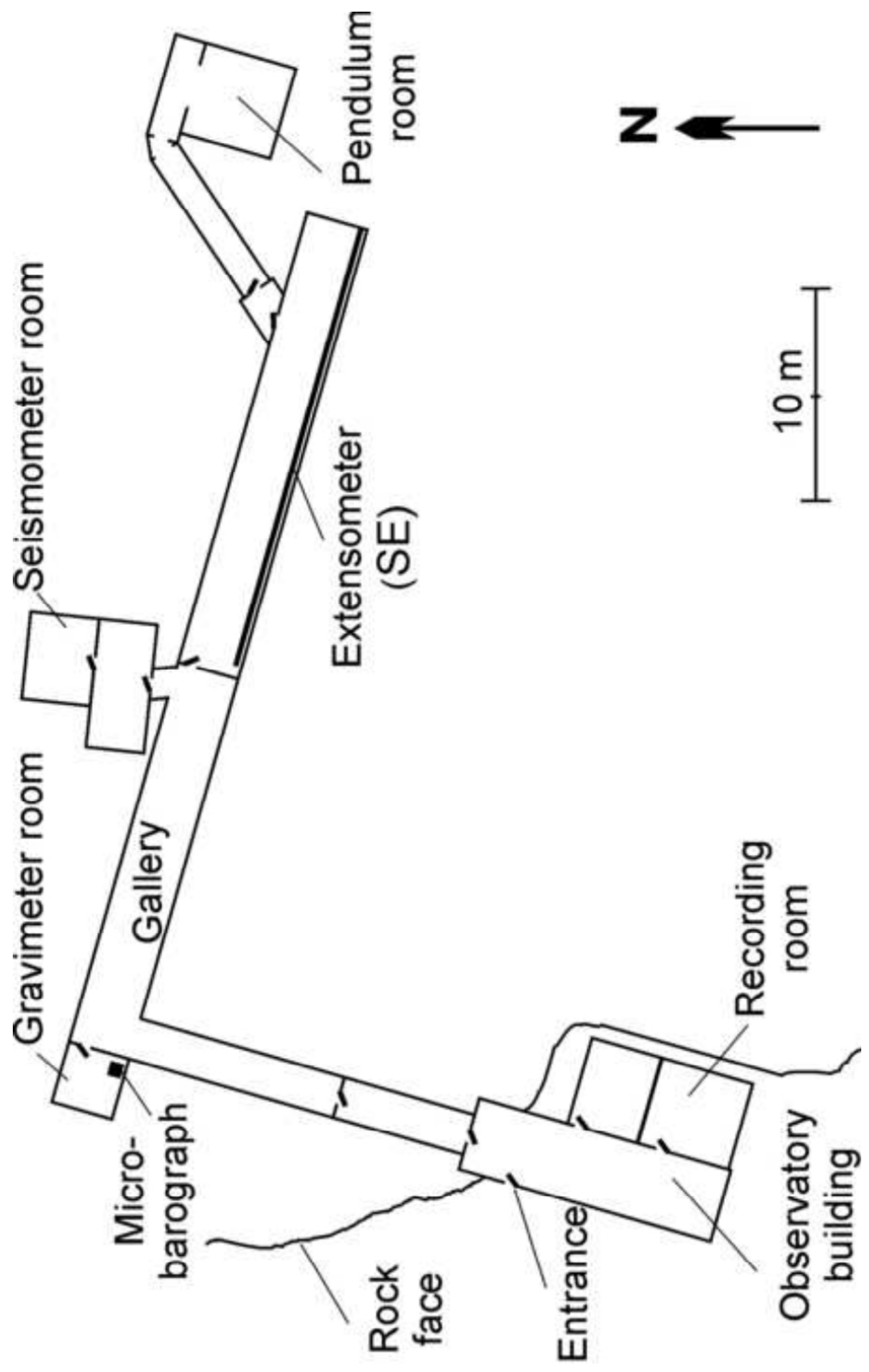




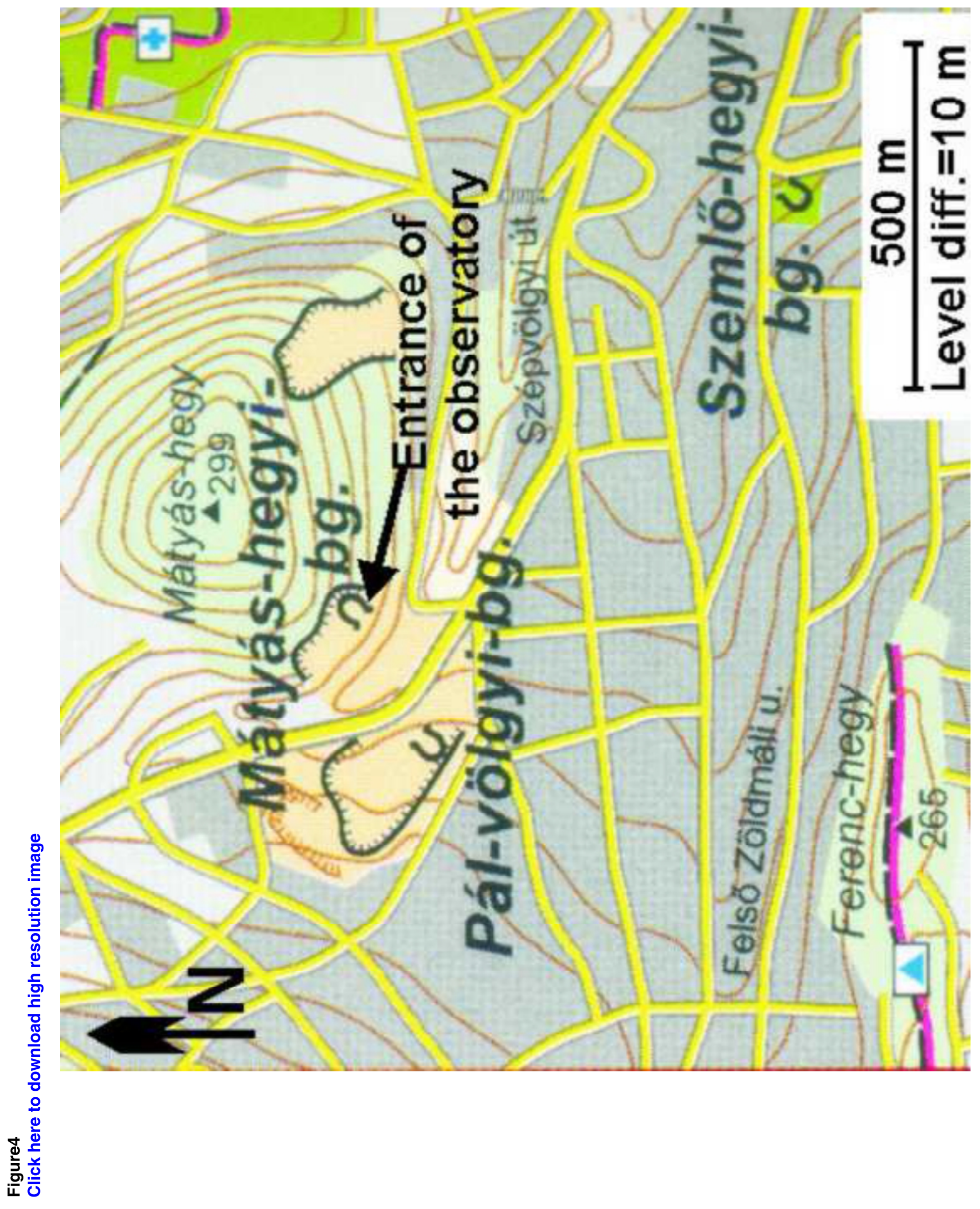




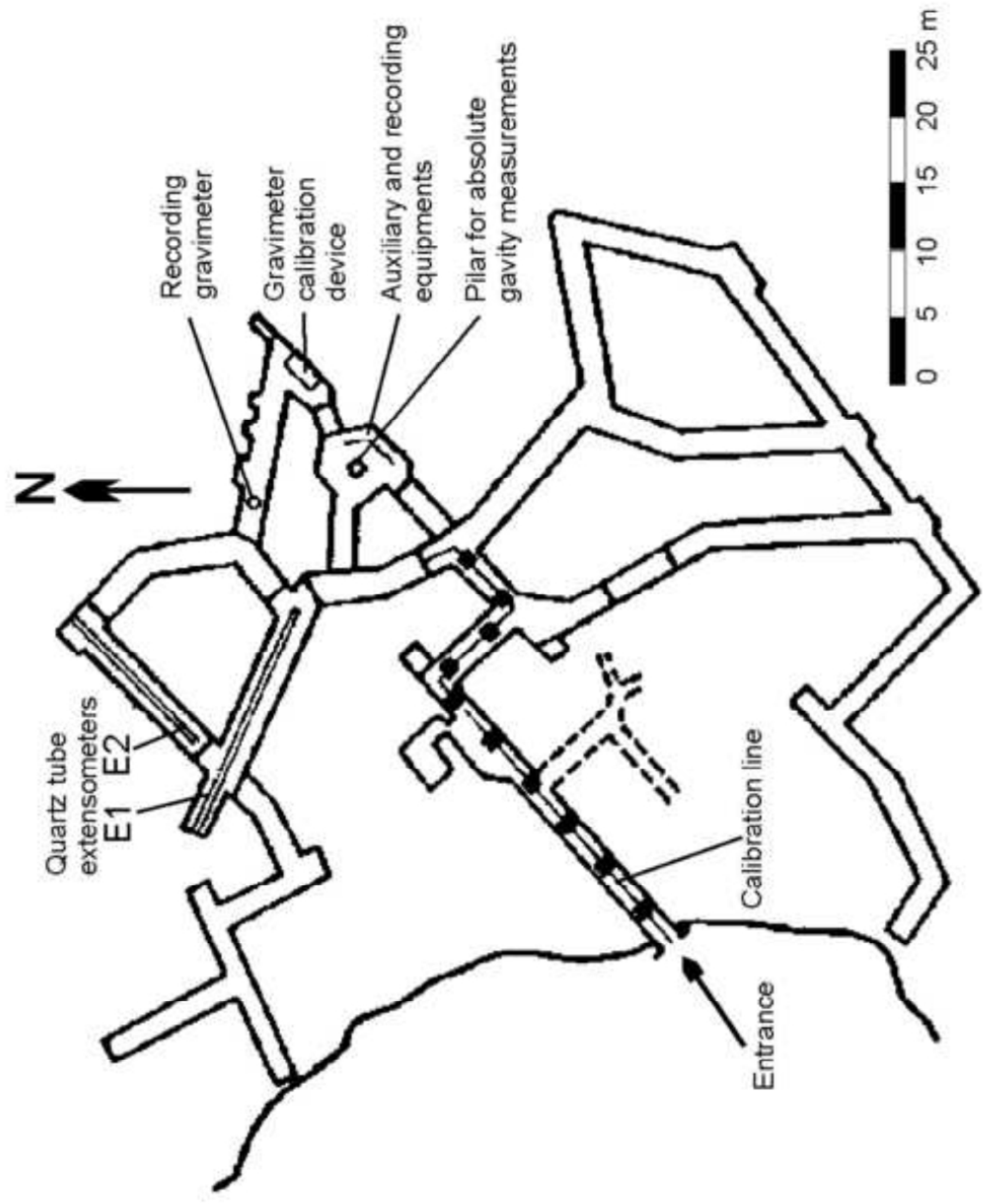



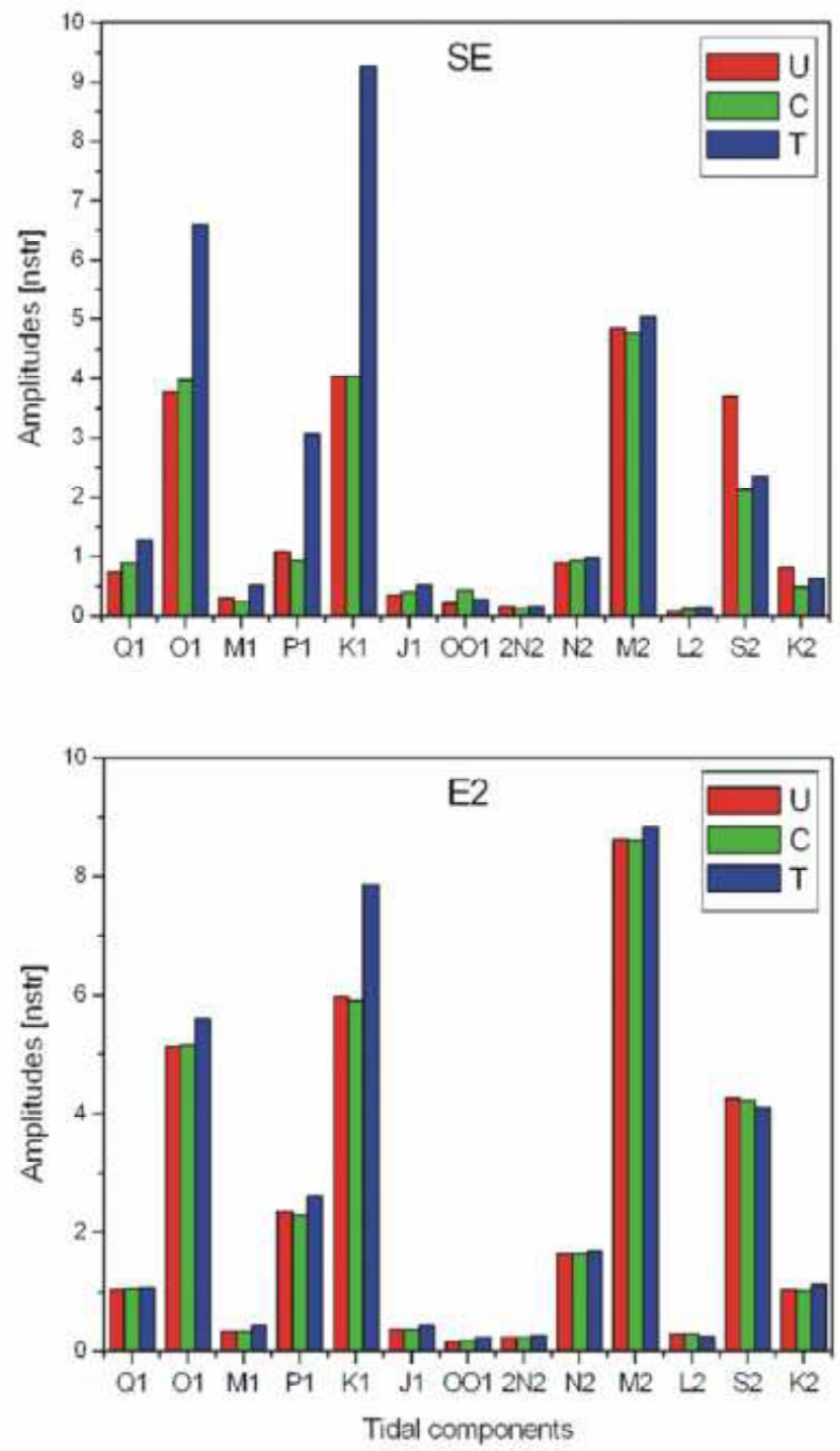

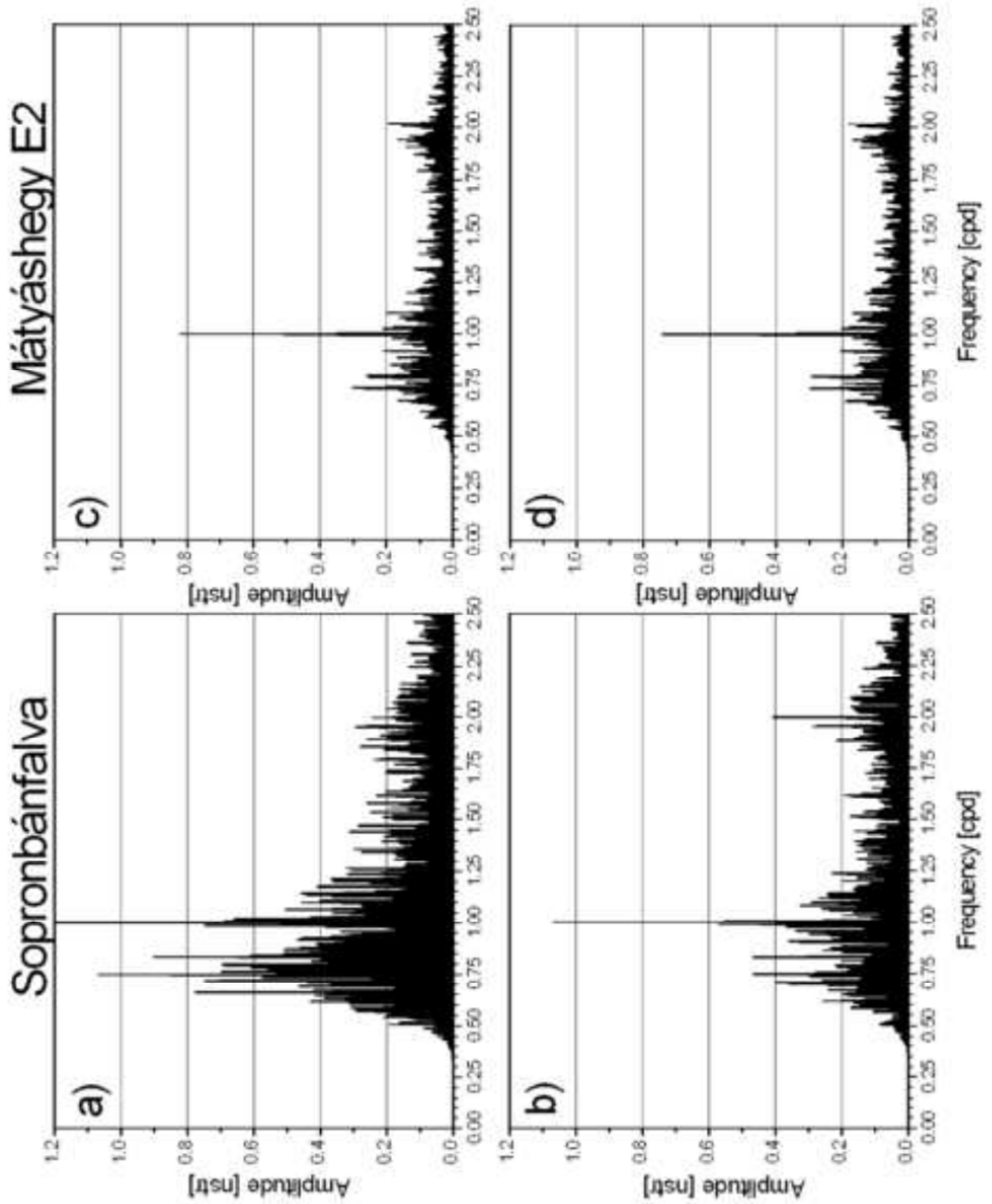

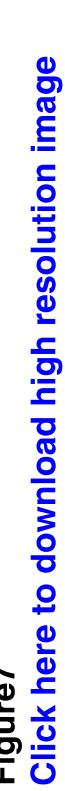




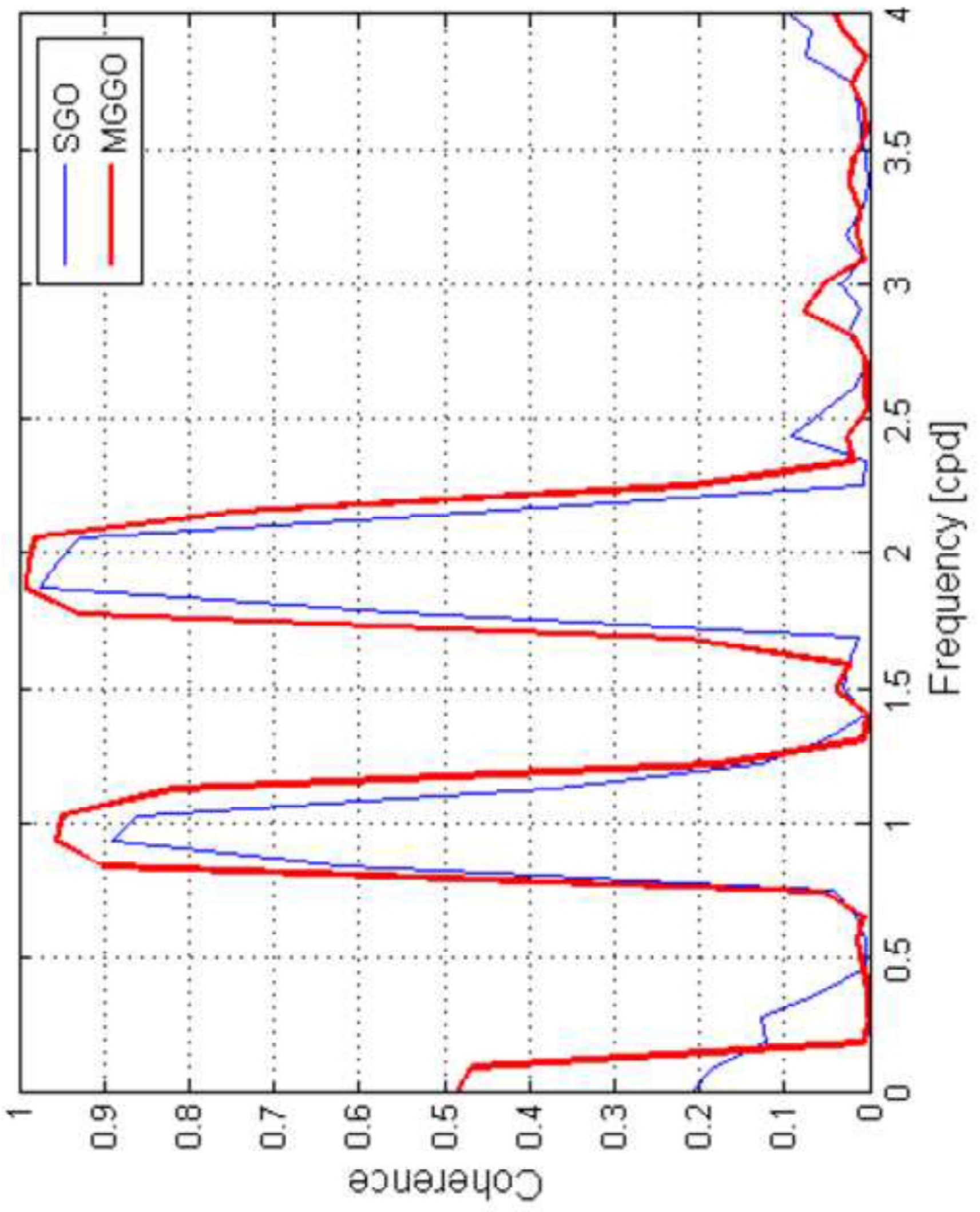




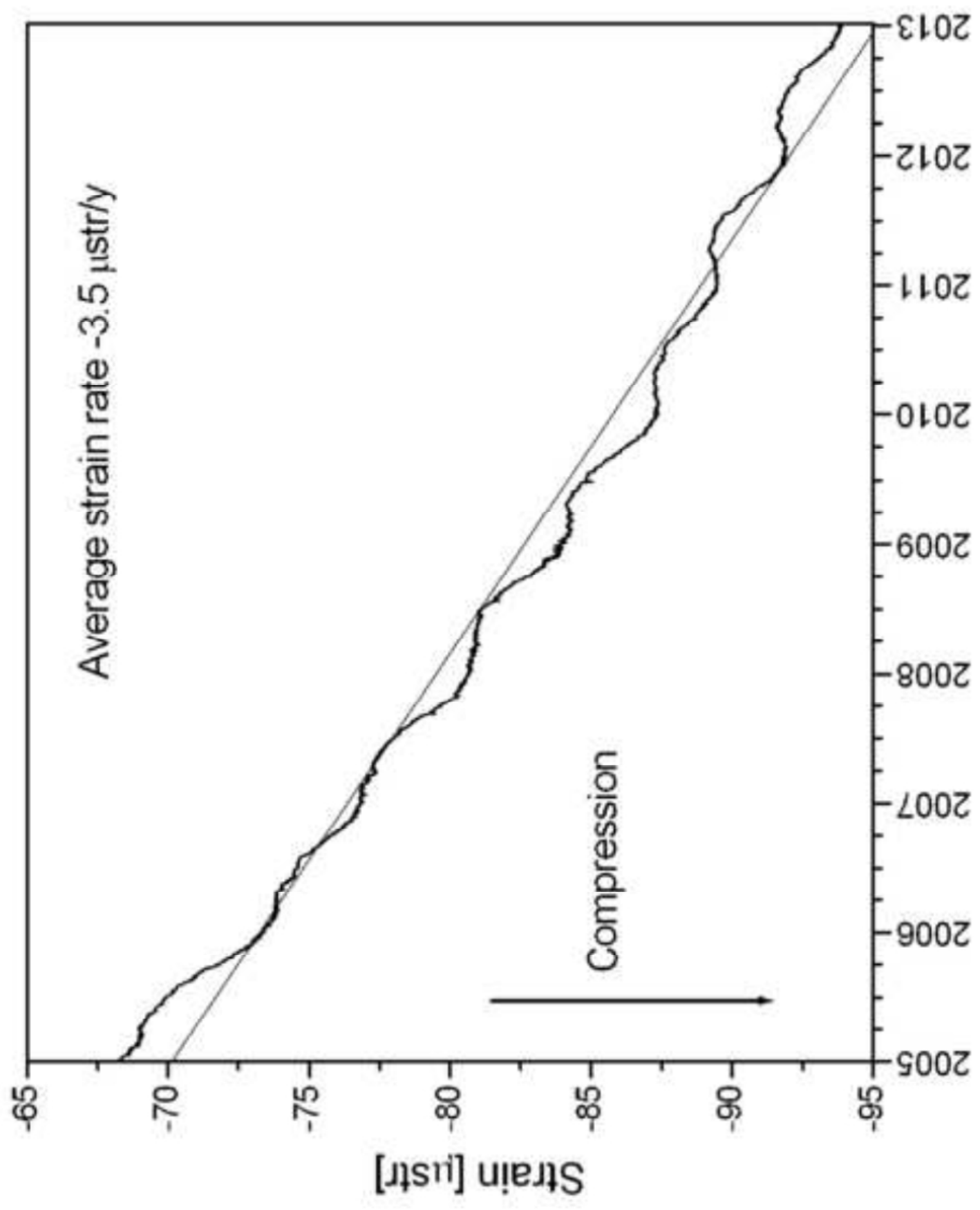




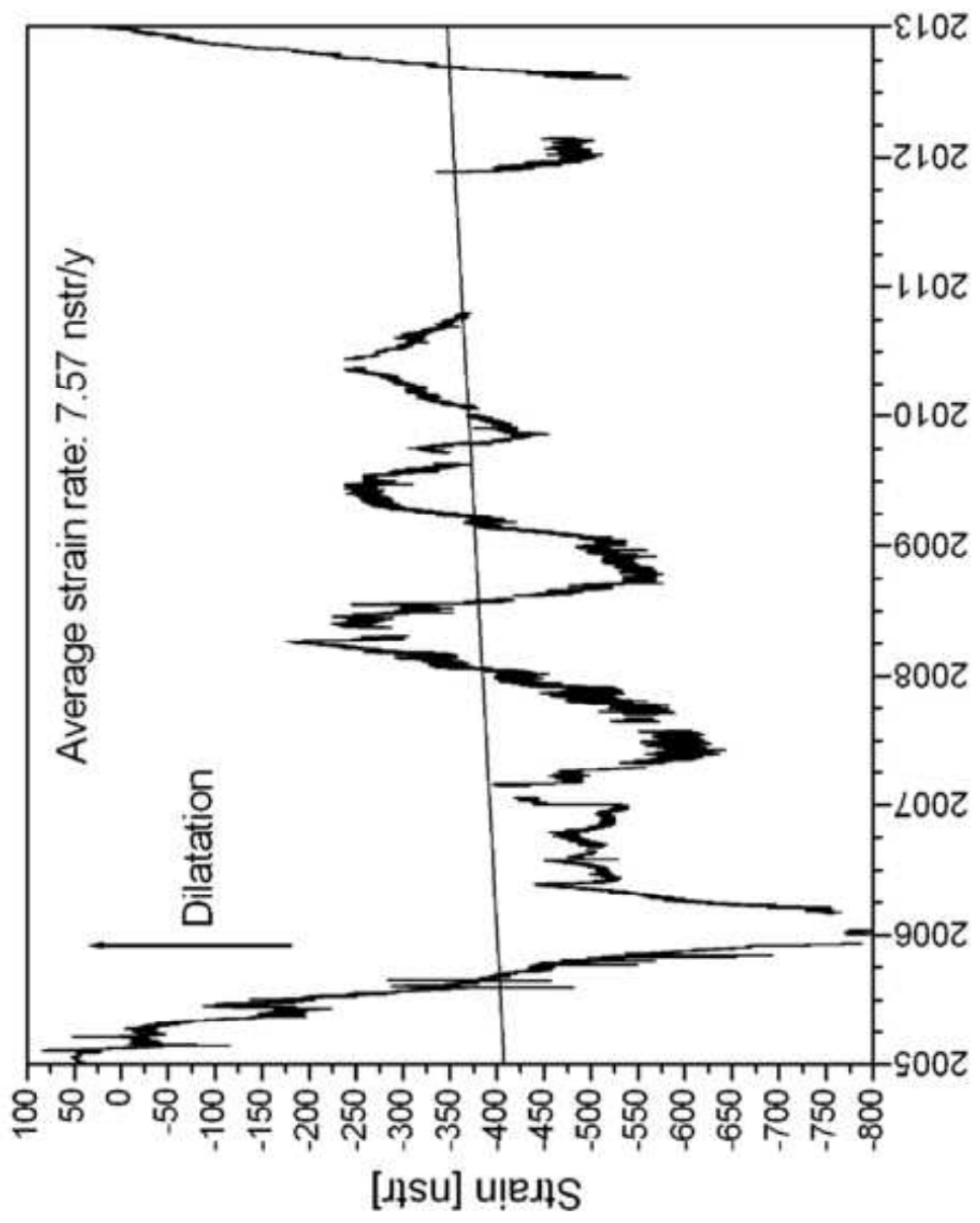




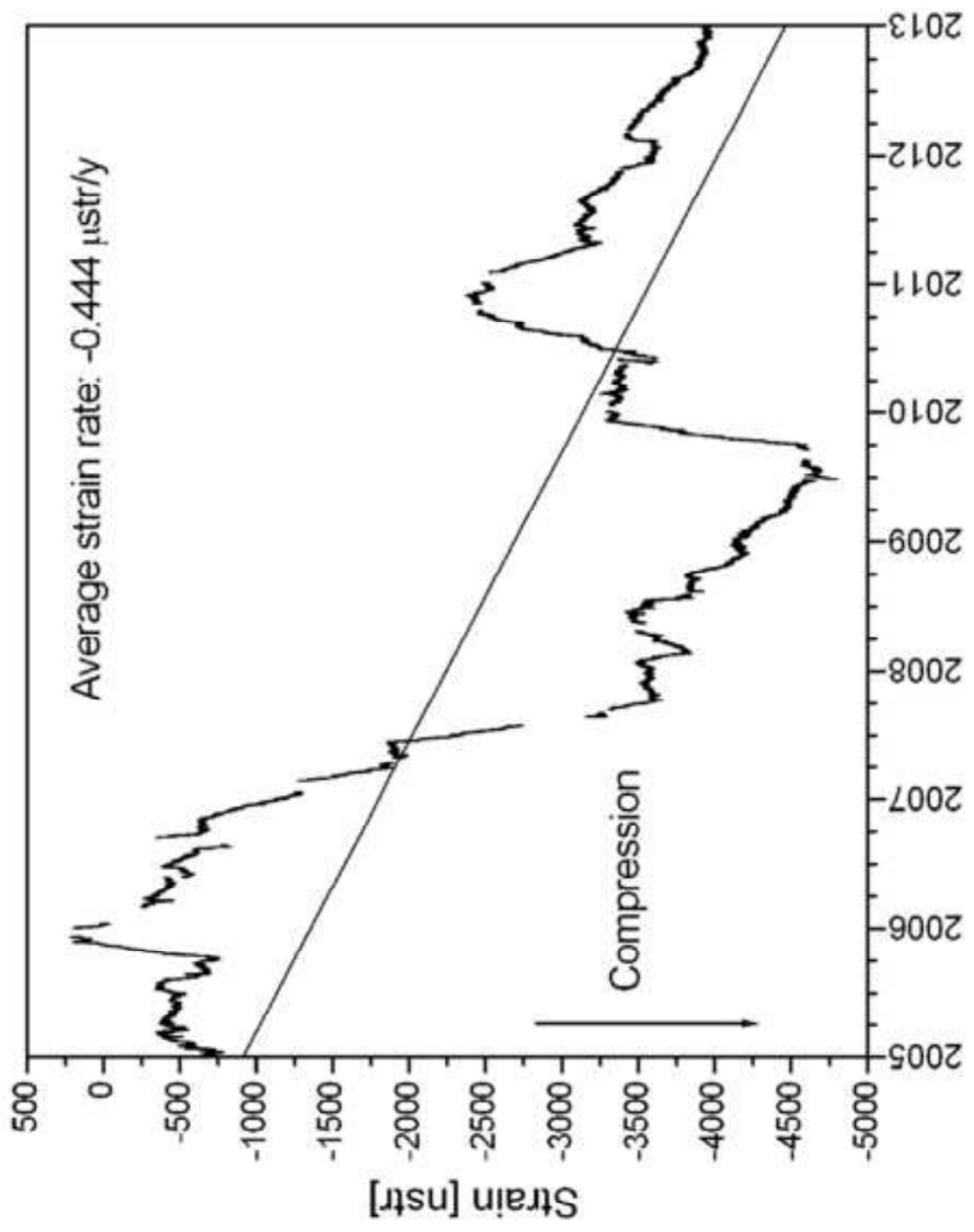


Table 1. Coordinates and parameters of the extensometers.

\begin{tabular}{|c|c|c|c|c|c|}
\hline \multirow[t]{2}{*}{ Extensometer } & \multicolumn{3}{|c|}{ Coordinates of the station } & \multirow{2}{*}{$\begin{array}{l}\text { Azimuth of the } \\
\text { instrument }\end{array}$} & \multirow{2}{*}{$\begin{array}{l}\text { Length of the } \\
\text { instrument [m] }\end{array}$} \\
\hline & Latitude & Longitude & Height a.s.l. $[\mathrm{m}]$ & & \\
\hline & '11" & $19^{\circ} 20^{\prime} 24^{\prime \prime}$ & 240 & $114^{\circ}$ & 21.3 \\
\hline & $33^{\prime} 11^{\prime \prime}$ & & 240 & $38^{\circ}$ & 13.8 \\
\hline Sopronbánfalva & $47^{\circ} 40^{\prime} 55^{\prime \prime}$ & $16^{\circ} 33^{\prime} 32^{\prime \prime}$ & 220 & $116^{\circ}$ & 22 \\
\hline
\end{tabular}




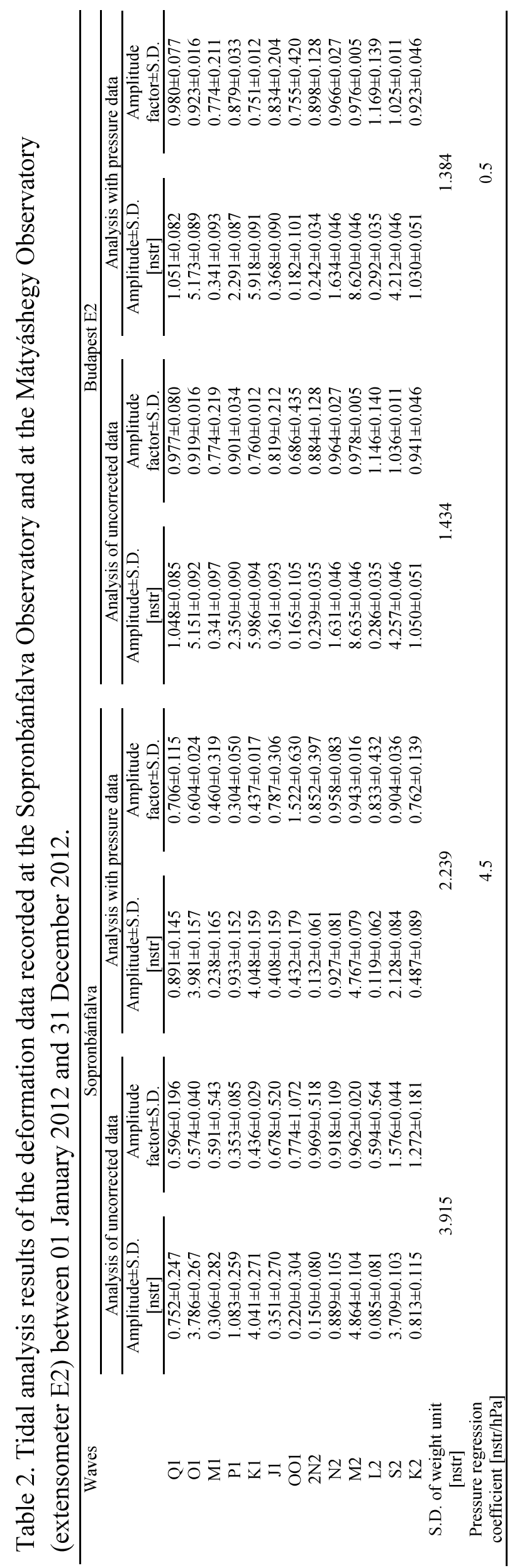


Table 3. Results of the long-term extensometric and geodetic measurements. (GPS SGO and GPS MGGO denote GPS measurements in the region of SGO and MGGO, respectively; HTN MGGO denote the strain rate determined from the Hungarian Triangulation Network in the region of the MGGO.)

\begin{tabular}{|c|c|c|c|c|c|}
\hline $\begin{array}{l}\text { Measuring } \\
\text { method }\end{array}$ & $\begin{array}{c}\text { Strain rate } \\
{\left[\mu \text { str year }^{-1}\right]}\end{array}$ & $\begin{array}{c}\text { Type of } \\
\text { deformation }\end{array}$ & $\begin{array}{l}\text { Admittance } \\
\mu \operatorname{str}^{\circ} \mathrm{C}^{-1}\end{array}$ & $\begin{array}{c}\text { Annual peak to peak } \\
\text { strain variation } \\
{[\mu \mathrm{str}]} \\
\end{array}$ & $\begin{array}{l}\text { Mesurement } \\
\text { period }\end{array}$ \\
\hline SGO E1 & -3.5 & compression & 0.023 & 1 & $2005-2012$ \\
\hline MGGO E1 & 0.0076 & extension & 0.009 & 0.4 & 2005-2012 \\
\hline MGGO E2 & -0.444 & compression & 0.006 & 0.3 & 2005-2012 \\
\hline MGGO E1 & -0.08 & compression & - & - & 1990-1992 \\
\hline MGGO E2 & -2.24 & compression & - & - & 1990-1992 \\
\hline GPS SGO & -0.008 & compression & - & - & 1991-2007 \\
\hline GPS MGGO & -0.004 & compression & - & - & 1991-2007 \\
\hline HTN MGGO & -0.08 & compression & - & - & $1878-1965$ \\
\hline
\end{tabular}


Table 4. Lithologic parameters of the rock around the observatories

\begin{tabular}{lcccc}
\hline Observatory & Rock material & $\begin{array}{c}\text { Density } \\
{\left[\mathrm{kg} \mathrm{m}^{-3}\right]}\end{array}$ & $\begin{array}{c}\text { Young's modulus } \\
{[\mathrm{GPa}]}\end{array}$ & Poisson ratio \\
\hline Sopronbánfalva & Gneiss & 2700 & 45.5 & 0.12 \\
Mátyáshegy & Limestone & 2500 & 65.0 & 0.25 \\
\hline
\end{tabular}

